\title{
Design and Simulation of GaAsN Based Solar Cell with AlGaAs blocking layer for Harvesting Visible to Near-infrared Light
}

Md Dulal Haque ${ }^{1 *}$, Md Hasan Ali ${ }^{2}$, Md Abdul Halim ${ }^{3}$, A. Z. M. Touhidul Islam ${ }^{4}$, Md Mahabub Hossain ${ }^{1}$, and M. Ismail Hossain ${ }^{5}$

${ }^{1}$ Department of Electronics and Communication Engineering, Hajee Mohammad Danesh Science and Technology University, Dinajpur-5200, Bangladesh.

${ }^{2}$ Department of Electrical and Electronic Engineerig, Begum Rokeya University, Rangpur-5404, Bangladesh.

${ }^{3}$ Department of Material Science and Engineering, University of Rajshahi, Rajshahi-6205, Bangladesh.

${ }^{4}$ Department of Electrical and Electronic Engineering, University of Rajshahi, Rajshahi-6205, Bangladesh.

${ }^{5}$ Department of Physics, University of Rajshahi, Rajshahi-6205, Bangladesh.

*Corresponding author (Dr. Md Dulal Haque)

E-mail: dhaque@hstu.ac.bd

\begin{abstract}
In the present study, the performance parameters of GaAsN dilute nitride-based semiconductor solar cell with and without AlGaAs blocking layers have been investigated in detail by Solar Cell Capacitance Simulator in one dimensional software program (SCAPS-1D). The thickness of absorber, buffer, and blocking layers are varied to achieve the improvement of open circuit voltage, short circuit current, fill factor, efficiency and also to optimize the device structure. The impact of doping and defect densities on the solar cell performance parameters have been analyzed minutely inside the absorber, buffer, and blocking layers. The solar cell thermal stability parameters are also investigated in the temperature region from $273 \mathrm{~K}$ to $373 \mathrm{~K}$. The efficiency of $43.90 \%$ and $40.05 \%$ are obtained from the proposed solar cells with and without AlGaAs blocking layer, respectively. The present findings may provide insightful approach for fabricating feasible, cost effective, and efficient dilute nitride solar cell.
\end{abstract}

Keywords: Efficiency, Performance parameters, Photo-generated carriers, SRH recombination and Carrier lifetime. 


\section{Introduction}

Dilute-nitride based solar cell structures have demonstrated much attention due to their potentiality to increase efficiency by adjusting band gap of alloy-based materials [1]. $G a A s / G a A s N$ structure has been designed for the application of space and large-scale power plant. The improvement of the efficiency of this structure is very much necessary for widening the application in different fields [2]. Solar cells are made of a single material ( $\mathrm{Si})$, and singlejunction (GaAs, CdTe, CuInGaSe) to compound materials, such as perovskite, dye-sensitized, inorganic, quantum dot, quantum well, and dilute nitride based solar cells [3]. Among them alloy based dilute nitride GaAsN compound semiconductor materials solar cell has unique properties. The alloys of GaAs-GaN provide the opportunity to fabricate GaAsN which recently attract the attention because of their negative and large band bowing (from -7 to $-40 \mathrm{eV}$ ) largely dependent on compositional properties. The offset of conduction band (>300 meV) is due to the size and

electro-negativity difference among $\mathrm{N}, \mathrm{Ga}$ and As atoms [4, 5]. The new sub-bands of energy can be constructed in the region of the lower energy of the conduction band by the addition of $\mathrm{N}$ inside the GaAs host materials which can be described by the band anti-crossing model. The structural properties of the new sub-band can be controlled properly by changing the amount of the incorporated $\mathrm{N}$ atoms inside the host GaAs. The new sub-band widens spectral response up to the infrared range, which contributes to raise the overall performance parameters of the cell [5-7].

The investigation about optical and morphological properties of GaAsN compound solar cell has been performed by different research groups [8-12]. The theoretical maximum efficiency of about $30.10 \%$ and $29.00 \%$ has been reported for optimized GaInP/GaAs/GaInNAs and GaInNAs solar cell [13]. The maximum conversion efficiency has been determined to be $24.94 \%$, when a hetero-structure configuration of $\mathrm{p}-\mathrm{GaAs} / \mathrm{p}-\mathrm{GaAsN} / \mathrm{n}-\mathrm{GaAs}$ is employed $\mathrm{n}-\mathrm{GaAs}$ as buffer layer, [14]. Another numerical study has achieved efficiency of $15.9 \%$ for the device structure of $\mathrm{n}^{+}$GaAs $/ n^{+}-G a A s N / p-G a A s N ~[15]$. The reported efficiency is much lower than the expected value in dilute nitride solar cell. The introduction of various defects in GaAsN during the incorporation of $\mathrm{N}$ atoms that reduces the number of generated photoelectrons causes this low efficient. The scattering of alloy and non-homogeneity of $\mathrm{N}$ atoms reduces the electron mobility and minority 
carrier lifetimes with enhanced nonradiative recombination of the flowing photo-generated carriers towards the electrodes and restricts to increase performance of GaAsN/GaAs solar cell $[7,11]$. The solar cell with AlGaAs blocking layer can significantly increases the open circuit voltage and consequently increase the efficiency [16]. In order to optimize the performance parameters of GaAsN cell, it is very much essential to investigate doping as well as quantum efficiency $(Q E)$, defect density, and the variation of different layer's thickness of the cell structure in presence of the AlGaAs blocking layer.

In this research work, we propose $\mathrm{p}^{+}-\mathrm{GaAs} / \mathrm{p}-\mathrm{GaAsN} / \mathrm{n}-\mathrm{GaAs}$ and $\mathrm{p}^{++} \mathrm{GaAs} / \mathrm{p}^{+} \mathrm{AlGaAs} / \mathrm{p}-$ $\mathrm{GaAsN} / \mathrm{n}-\mathrm{AlGaAs} / \mathrm{n}^{+} \mathrm{GaAs}$ solar cell structures to investigate the short circuit current $\left(J_{s c}\right)$, open circuit voltage $\left(V_{o c}\right)$, fill factor $(F F)$, efficiency $(\eta)$ as performance parameters, and $Q E$ by the SCAPS-1D with and without AlGaAs blocking layer. This research demonstrates the modeled pGaAsN solar cell with AlGaAs blocking layer can achieve the improvement of $V_{o c}$ and $\eta$.

\section{Device structure and simulation}

Figure 1 illustrates the schematic structure of $\mathrm{p}^{+}-\mathrm{GaAs} / \mathrm{p}-\mathrm{GaAsN} / \mathrm{n}-\mathrm{GaAs}$ (Cell 1) and $\mathrm{p}^{++}$ GaAs/p $\mathrm{p}^{+} \mathrm{AlGaAs} / \mathrm{p}-\mathrm{GaAsN} / \mathrm{n}-\mathrm{AlGaAs} / \mathrm{n}^{+}$-GaAs (Cell 2), respectively.

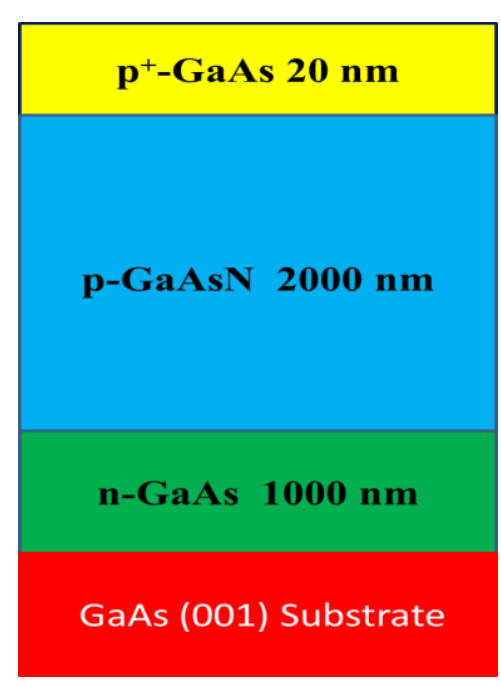

(a) Cell 1

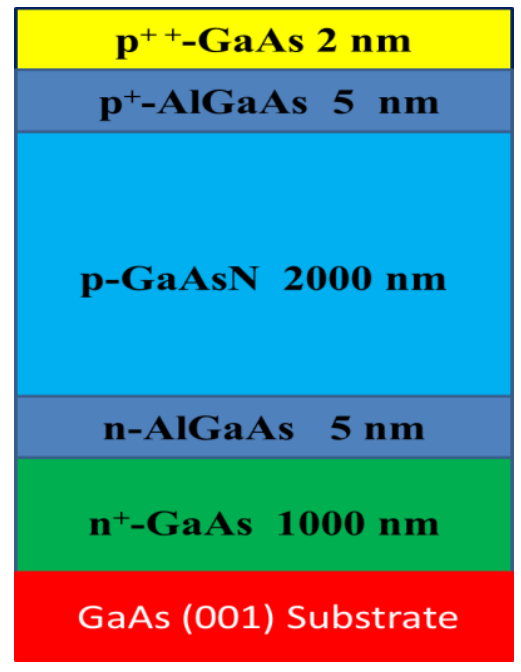

(b) Cell 2

Fig.1 Designed and optimized structure of solar cell (a) Cell 1: $\mathrm{p}^{+}-\mathrm{GaAs} / \mathrm{p}-\mathrm{GaAsN} / \mathrm{n}-\mathrm{GaAs}$ and (b) Cell 2: $\mathrm{p}^{++}-\mathrm{GaAs} / \mathrm{p}^{+}-\mathrm{AlGaAs} / \mathrm{p}-\mathrm{GaAsN} / \mathrm{n}-\mathrm{AlGaAs} / \mathrm{n}^{+}-\mathrm{GaAs}$. 
Table 1: Physical parameters of different layers required in the device modeling.

\begin{tabular}{|c|c|c|c|}
\hline Parameters (unit) & GaAs & GaAsN & AlGaAs \\
\hline Conductivity & $\mathrm{p}^{++} / \mathrm{p}^{+} / / \mathrm{n} / \mathrm{n}^{+}$ & $\mathrm{p}$ & $\mathrm{p}^{+} / \mathrm{n}$ \\
\hline${ }^{*}$ Thickness, $W(\mathrm{~nm})$ & $2 / 20 / 1000 / 1000$ & 2000 & $5 / 5$ \\
\hline Bandgap, $E_{\mathrm{g}}(e V)$ & $1.42[14,18]$ & $1.33[14]$ & $1.81[19,20]$ \\
\hline Electron affinity, $\chi(e V)$ & $4.07[14,18,21]$ & $4.071[14,22]$ & $3.74[19,20]$ \\
\hline Dielectric permittivity (relative), $\varepsilon_{\mathrm{r}}$ & $12.5[14,23]$ & $12.38[14]$ & $12.1[20,24]$ \\
\hline $\begin{array}{l}\text { Effective conduction band density, } N_{C} \\
\left(\mathrm{~cm}^{-3}\right)\end{array}$ & $\begin{array}{c}4.33 \times 10^{17} \\
{[14,22,25]}\end{array}$ & $\begin{array}{l}4.66 \times 10^{17} \\
{[14][22]}\end{array}$ & $\begin{array}{c}6.52 \times 10^{17} \\
{[24]}\end{array}$ \\
\hline Effective valence band density, $N_{V}\left(\mathrm{~cm}^{-3}\right)$ & $1.28 \times 10^{19}[1,3,7]$ & $1.39 \times 10^{19}[1]$ & $\begin{array}{c}1.12 \times 10^{19} \\
{[24]}\end{array}$ \\
\hline Mobility of electron, $\mu_{\mathrm{n}}\left(\mathrm{cm}^{2} V^{1} \mathrm{~s}^{-1}\right)$ & $8500[14,18,21]$ & $6538.46[14,22]$ & $2300[19,20]$ \\
\hline Mobility of hole, $\mu_{\mathrm{p}}\left(\mathrm{cm}^{2} V^{1} \mathrm{~s}^{-1}\right)$ & $400[14,18,21]$ & $397.72[14,22]$ & $150[19][19]$ \\
\hline${ }^{*}$ Concentration of donor, $N_{D}\left(\mathrm{~cm}^{-3}\right)$ & $\begin{array}{c}1.0 \times 10^{16} / \\
1.0 \times 10^{18}[14]\end{array}$ & 0 & $1 \times 10^{17}[26]$ \\
\hline Concentration of acceptor $N_{A}\left(\mathrm{~cm}^{-3}\right)$ & $\begin{array}{c}5.0 \times 10^{19} / 5.0 \times 10^{19} \\
{[14]}\end{array}$ & $1 \times 10^{16}$ & $1 \times 10^{17}[24]$ \\
\hline Defect type & $\begin{array}{c}\text { Donor/ Donor/ } \\
\text { Acceptor/ Acceptor }\end{array}$ & Donor & $\begin{array}{c}\text { Donor } \\
\text { /Acceptor }\end{array}$ \\
\hline Energetic distribution & Gaussian & Gaussian & Gaussian \\
\hline${ }^{*}$ Bulk defect density, $N(t)$ total $\left(\mathrm{cm}^{-3}\right)$ & $1.0 \times 10^{14}$ & $1.0 \times 10^{14}$ & $1.0 \times 10^{14}$ \\
\hline Characteristic energy $(\mathrm{eV})$ & 0.10 & 0.10 & 0.10 \\
\hline Reference energy $(\mathrm{eV})$ & 0.71 & 0.665 & 0.905 \\
\hline $\begin{array}{l}\text { Capture cross section of electron for } \\
\text { acceptor defect }\left(\mathrm{cm}^{-2}\right)\end{array}$ & $1.0 \times 10^{-17}$ & - & $1.0 \times 10^{-17}$ \\
\hline $\begin{array}{l}\text { Capture cross section of hole for acceptor } \\
\text { defect }\left(\mathrm{cm}^{-2}\right)\end{array}$ & $1.0 \times 10^{-15}$ & - & $1.0 \times 10^{-15}$ \\
\hline $\begin{array}{l}\text { Capture cross section of electron for } \\
\text { donor defect }\left(\mathrm{cm}^{-2}\right)\end{array}$ & $1.0 \times 10^{-15}$ & $1.0 \times 10^{-15}$ & $1.0 \times 10^{-15}$ \\
\hline $\begin{array}{l}\text { Capture cross section of hole for donor } \\
\text { defect }\left(\mathrm{cm}^{-2}\right)\end{array}$ & $1.0 \times 10^{-17}$ & $1.0 \times 10^{-17}$ & $1.0 \times 10^{-17}$ \\
\hline
\end{tabular}

* Indicates the variable parameters.

For designing the Cell 1 and Cell 2, a $20 \mathrm{~nm} \mathrm{p}^{+}$-GaAs and $2 \mathrm{~nm} \mathrm{p}^{++}$-GaAs layers are used as the cap layer with acceptor density $N_{A}=5.0 \times 10^{19} \mathrm{~cm}^{-3}$. A highly doped $1000 \mathrm{~nm} \mathrm{n-GaAs} \mathrm{and} \mathrm{n}^{+}$ GaAs with doping concentration $1 \times 10^{16} \mathrm{~cm}^{-3}$ and $1 \times 10^{18} \mathrm{~cm}^{-3}$ are also used as buffer layers for Cell 1 and Cell 2, respectively. The p-GaAsN layer of $2000 \mathrm{~nm}$ with $N_{A}=1 \times 10^{16} \mathrm{~cm}^{-3}$ is employed as the absorber layer for both Cell 1 and Cell 2. The silicon doped GaAs layers are 
also considered as a substrate for both the proposed solar cells. The additional n-AlGaAs layer (above the buffer layer) and $\mathrm{p}^{+}-\mathrm{AlGaAs}$ layer (below the cap layer), each thickness of $5 \mathrm{~nm}$, are also used in Cell 2 as blocking layers to improve the performance parameters. The simulation and investigation are performed by the Solar Cell Capacitance Simulator one dimensional simulation software (SCAPS-1D). The SCAPS-1D provides the opportunity to solar cell researcher to analyze device structure of maximum seven layers. It is a very useful tool used to perform electrical characterizations and spectral response of solar cell. It enables to analyze the tunneling effect, energetic distribution of the defects, carrier generation and recombination [17]. The solar cells are illuminated under $100 \mathrm{~mW} / \mathrm{cm}^{2}$ (1sun) with global air mas AM 1.5 G solar spectrum at operating temperature $300 \mathrm{~K}$, considering ideal condition for the series $\left(R_{s}\right)$ and shunt $\left(R_{s h}\right)$ resistances. The simulation parameters are adopted from previously studied research works as presented in Table 1.

\section{Results and Discussion:}

\subsection{Energy band diagram of designed solar cell}

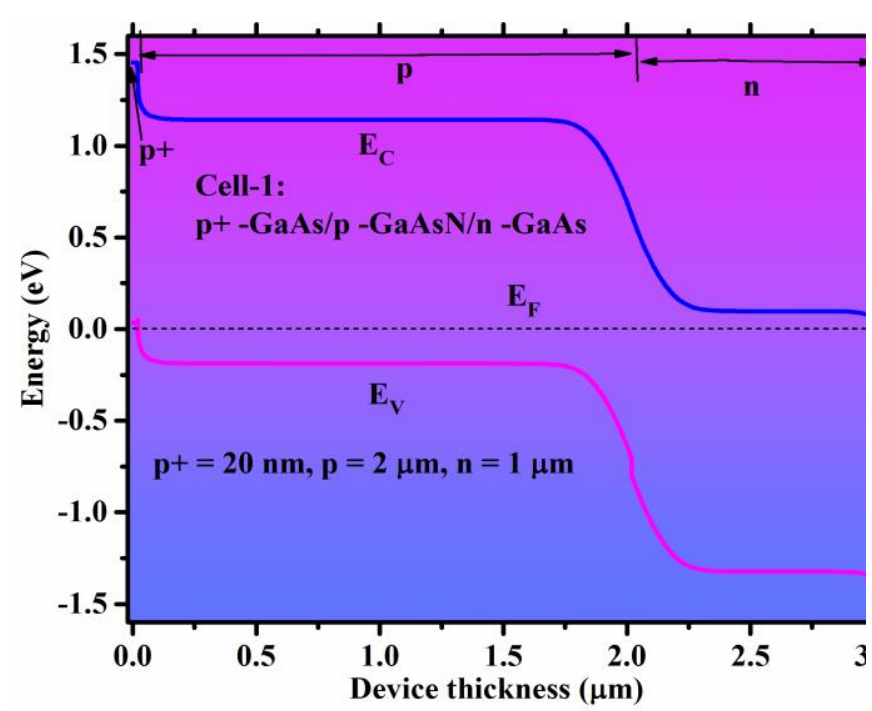

(a)

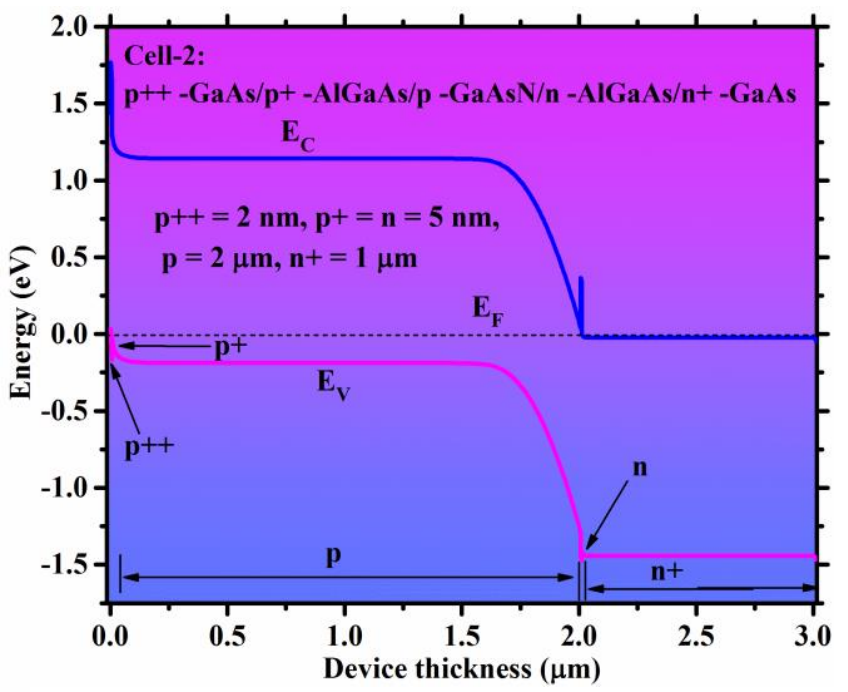

(b)

Fig. 2 Energy band diagram of the designed solar cells at a bias voltage of $0 \mathrm{~V}$ for (a) Cell 1 and (b) Cell 2.

This research has been done by the numerical simulation to analyze p-GaAsN based solar cell that demonstrates enhancement of conversion efficiency with minimal absorber layer thickness. 
Total device structure and different layers' thickness as well as doping concentration are necessary to be optimized to fabricate a high efficiency solar cell in view to reduce fabrication time and cost, thus enhance production throughput. The thermodynamic equilibrium band diagram of $p^{+}-G a A s / p-G a A s N / n-G a A s$ and $p^{++}-G a A s / p^{+}-A l G a A s / p-G a A s N / n^{+}-A l G a A s / n^{+}-G a A s$ dilute nitrite structures, performed by SCAPS-1D simulator, are schematically depicted in Figs. 2(a) and 2(b), respectively. The band diagram structure mainly depends on the band gap energy $\left(E_{g}\right)$, electron affinity $(\chi)$, and density of doping and defect of the adjacent layers. The value of $\chi$ for GaAsN absorber and GaAs layers are assumed to be $4.071 \mathrm{eV}$ and $4.07 \mathrm{eV}$ for Cell 1 and Cell 2, respectively, while for AlGaAs, $\chi$ is $3.74 \mathrm{eV}[1,7]$. The energy difference between the conduction band minima $\left(E_{c}\right)$ and the valence band maxima $\left(E_{v}\right)$ is illustrated as $E_{g}$ for each layer. The position of Fermi energy level $E_{F}$ with respect to $E_{c}$ and $E_{v}$ changes due to the variation of operating temperature, density of doping, number of free carriers (electrons and holes), and their effective masses. The position of $E_{F}$ moves toward $E_{c}$ in n-type from the midgap position, while it moves away from $E_{v}$ in p-type semiconductor. However, the better $\eta$ is achieved for Cell 2 with AlGaAs blocking layer.

\subsection{Effect of thickness on PV parameters}

The effect of solar cell performance with respect to different layer thickness in Cell 1 and Cell 2 are shown in Figs. 3.

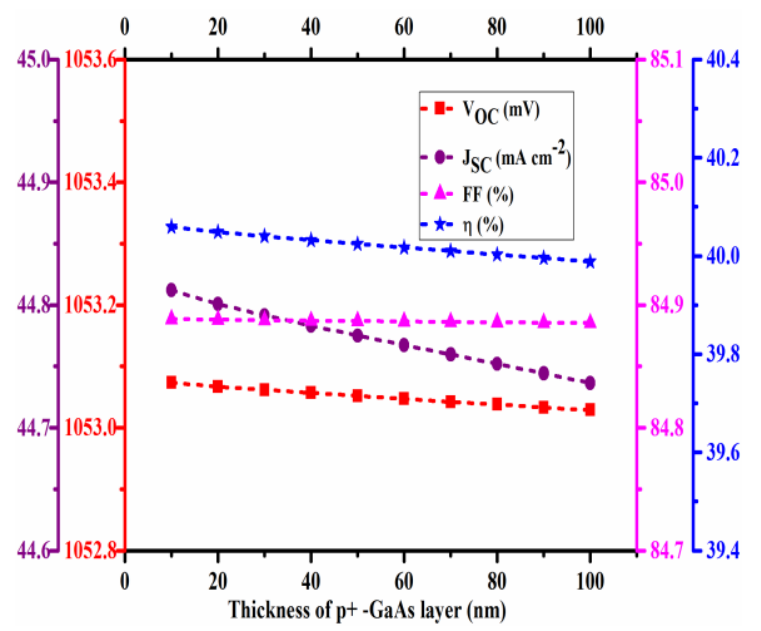

(a)

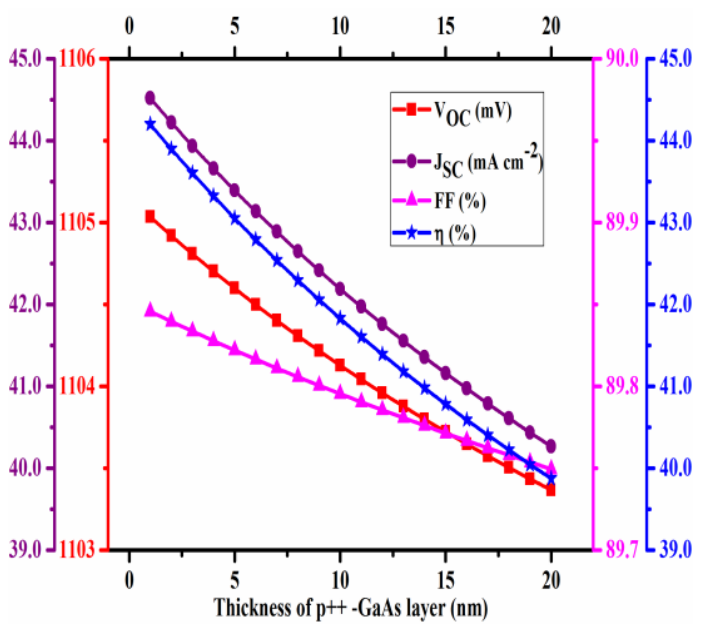

(b) 


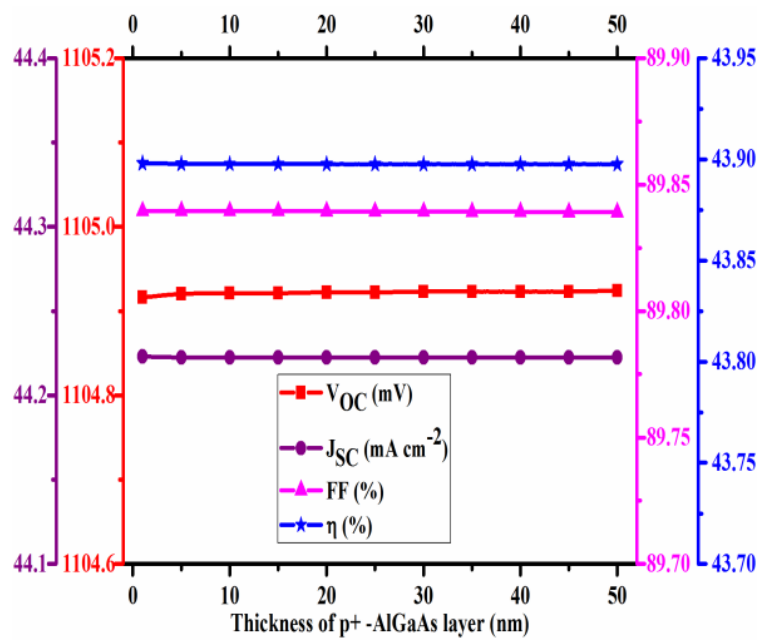

(c)

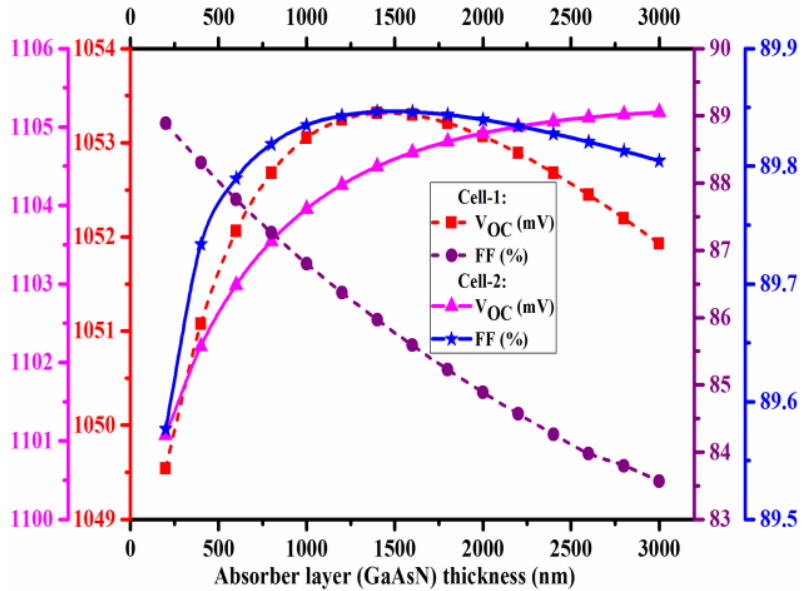

(e)

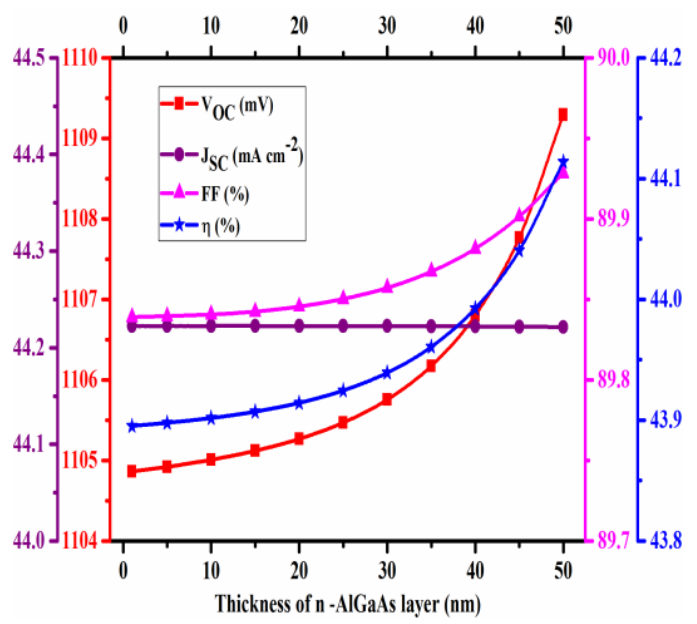

(d)

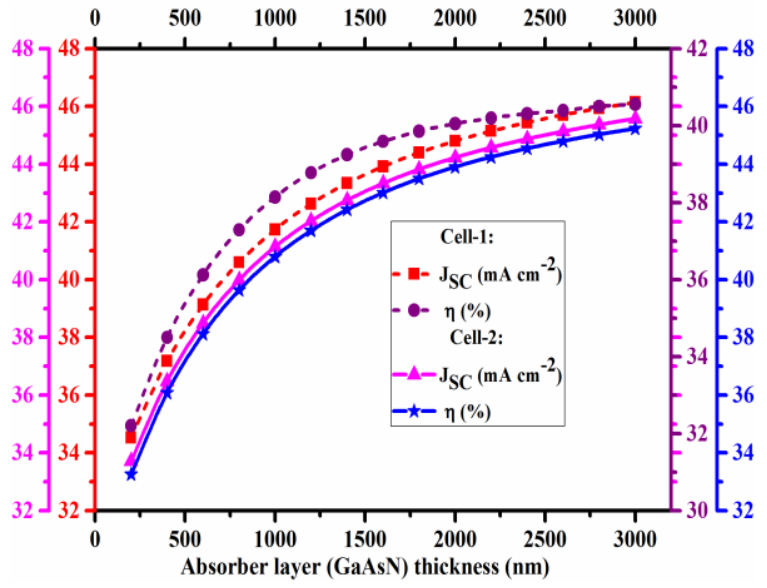

(f) 


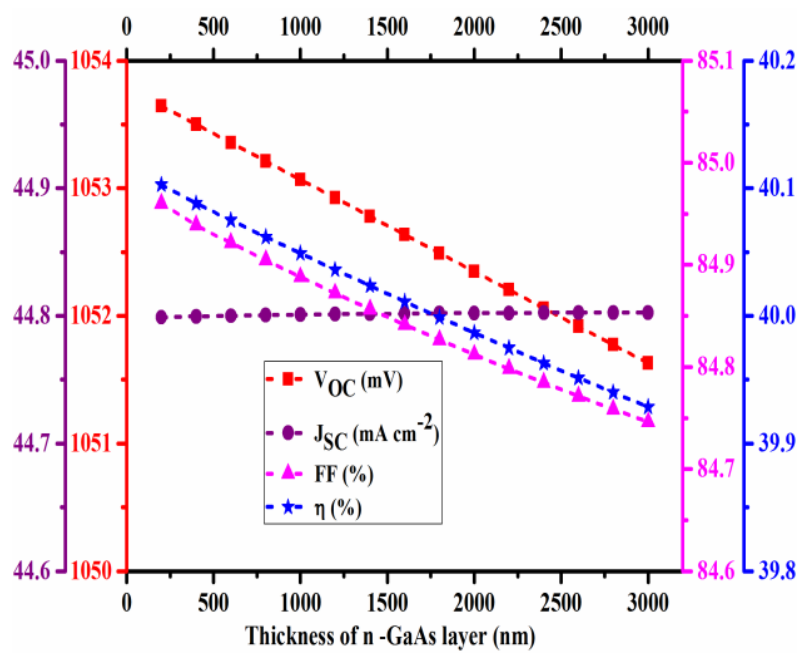

$(\mathrm{g})$

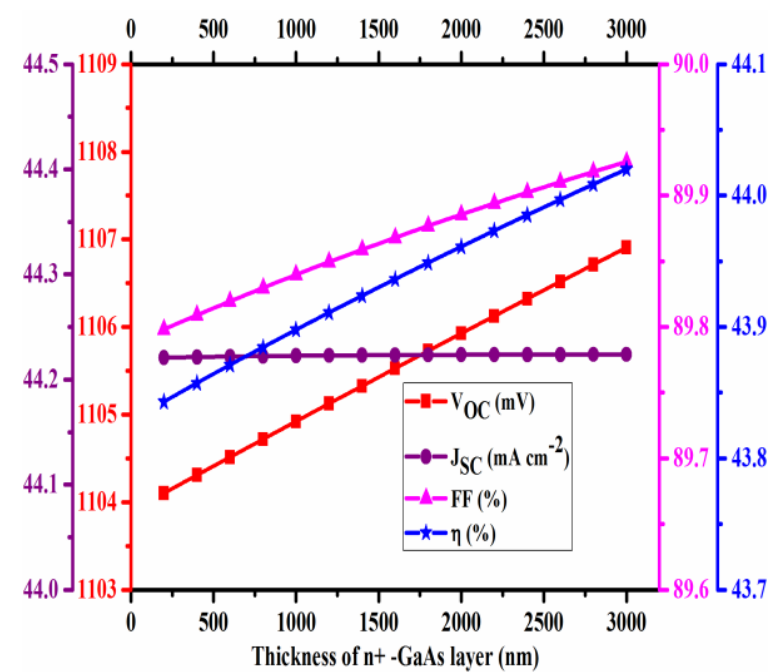

(h)

Fig. 3 The effect of solar cell performance with respect to different layer thickness for (a) $\mathrm{p}^{+}-$ GaAs layer of Cell 1 (b) $\mathrm{p}^{++}$-GaAs layer in Cell 2 (c) and (d) $\mathrm{p}^{+}$-AlGaAs and n-AlGaAs layers, respectively in Cell 2, (e) and (f) p-GaAsN layer in Cell 1 and Cell 2, respectively (g) n-GaAs layer in Cell 1 and (h) $\mathrm{n}^{+}$-GaAs layer in Cell 2. Here the 'broken lines' indicate the data for Cell 1 whereas, the solid lines for Cell 2.

Figures 3(a), and 3(b) represents the variation of $V_{o c}, J_{s c}, F F$ and $\eta$ due to change of the thickness of $\mathrm{p}^{+}-\mathrm{GaAs}$ and $\mathrm{p}^{++}$-GaAs cap layers in Cell 1 and Cell 2, respectively. It is observed that with the increase of the thickness of $\mathrm{p}^{+}$-GaAs from 10 to $100 \mathrm{~nm}$ in Cell 1 (Fig. 3(a)), the solar cell output parameters $V_{o c}, J_{s c}, F F$ and $\eta$ decreases slowly compared to that of Cell 2, where the thickness changes from 1 to $20 \mathrm{~nm}$ (Fig. 3(b)). With the enhancement of thickness of the cap layers $\mathrm{p}^{+}-\mathrm{GaAs}$ and $\mathrm{p}^{++}-\mathrm{GaAs}$ in Cell 1 and Cell 2, respectively, a smaller number of photons is absorbed inside the p-GaAsN layer which results in the decrease of the number of electron-hole pair generation. Hence, the overall performance parameters decrease. This type of degradation in $V_{o c}, J_{s c}, F F$ and $\eta$ has been reported in previous studies $[14,15]$. The effect on the change of the thickness of $\mathrm{p}^{+}$-AlGaAs and n-AlGaAs blocking layers is shown in Figs. 3(c) and 3(d), respectively, for Cell 2 (Fig. 1(b)). It is observed from the results that due the variation of the thickness of the layer $\mathrm{p}^{+}-\mathrm{AlGaAs}$, there is no change of the solar cell output parameters (Fig. 3(c)), while $V_{o c}, F F$ and $\eta$ enhances owing to the rise of the thickness of the layer n-AlGaAs in Cell 2 (Fig. 3(d)). The improvement of these performance parameters may be due to the change 
of offset voltage (band alignment) with the increase of n-AlGaAs layer thickness [27-29]. Figures 3(e) and 3(f) represent the variation of $V_{o c}, J_{s c}, F F$ and $\eta$ due to the change of thickness of p-GaAsN absorber layer at $300 \mathrm{~K}$ for Cell 1 and Cell 2, respectively. It is obvious from Fig. 3(e) that with increasing the thickness of p-GaAsN layer from $200 \mathrm{~nm}$ to $3000 \mathrm{~nm}$, the value of $V_{o c}$ monotonically increases from 1101 to $1105 \mathrm{mV}$ whereas the value of FF sharply increases from 89.58 and reaches a maximum value to 89.85 at around $1400 \mathrm{~nm}$, after that it is monotonically decreases to 83.57 for Cell 2. With rising the thickness of p-GaAsN from $200 \mathrm{~nm}$ to $3000 \mathrm{~nm}$ (Fig. 3(f)), the values of $J_{s c}$ and $\eta$ increases monotonically from 34.53 to 46.13 $\mathrm{mAcm}^{-2}$ and 32.21 to $40.56 \%$, respectively for Cell 1 and 33.72 to $45.57 \mathrm{mAcm}^{-2}$ and 33.25 to 45.23, respectively for Cell 2. The decrease of the values of solar cell parameters is due to the small number of photons absorption at lower thickness and higher recombination rate of free electrons and holes before they move toward the electrodes. A thicker layer enables to enhance the photons absorption and create large number of electron hole pairs, which dominantly enhances amount of the photo-generated current [28, 30, 31]. However, thicker absorber layer increases the solar cell fabrication cost significantly. Hence considering overall consequences, it is necessary to investigate thickness dependency of absorber layer. The thickness dependency of

n-GaAs and $\mathrm{n}^{+}$-GaAs layers for the photovoltaic parameters of $V_{o c}, J_{s c}, F F$, and $\eta$ for Cell 1 and Cell 2 has been investigated as illustrated in figure $3(\mathrm{~g})$ and $3(\mathrm{~h})$, respectively. It is observed that with increasing the thickness of $\mathrm{n}$-GaAs layer, the photovoltaic parameters $V_{o c}, J_{s c}$, and $\eta$ decreases constantly for Cell 1 (Fig. 3(g)) while these values show increasing tendency for Cell 2 (Fig. 3(h)). However, the value of FF remains constant for both Cell 1 and Cell 2. The increase of n-GaAs layer thickness may enhance the threading dislocation density, which results in decrease of $V_{o c}$ as well as $\eta$. The presence of AlGaAs blocking layer with the $\mathrm{n}^{+}$-GaAs layer in Cell 2, changes band alignment which enhances the values of $V_{o c} F F$, and $\eta$ as shown in Fig. 3(h) [27-29].

\subsection{Impact of thickness on the quantum efficiency}

The effect of GaAsN layer thickness on quantum efficiency $(Q E)$ for solar Cell 1 and Cell 2 are demonstrated in Fig. 4. 


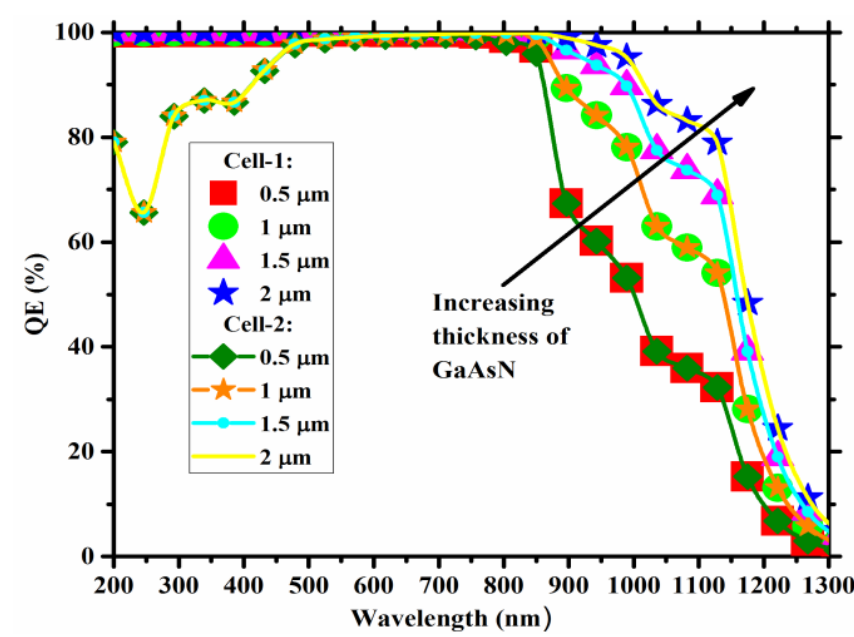

Fig. 4 Quantum efficiency versus thickness of GaAsN layer for solar Cell 1 and Cell 2.

In this study, the absorber layer thickness has been varied from 0.5 to $2 \mu \mathrm{m}$ for both solar cells at the doping density of $1.0 \times 10^{16} \mathrm{~cm}^{-3}$. The thickness of $\mathrm{p}^{+}-\mathrm{GaAs}$ and $\mathrm{n}-\mathrm{GaAs}$ are fixed at $20 \mathrm{~nm}$ and $1000 \mathrm{~nm}$, respectively for Cell 1 . For Cell 2, the thickness of $\mathrm{p}^{++}$-GaAs and $\mathrm{n}^{+}$-GaAs are 2 $\mathrm{nm}$ and $1000 \mathrm{~nm}$, respectively. The p-GaAsN enables to absorb illuminated lights from 200 to $1300 \mathrm{~nm}$ at different depth of the layer as indicated in Fig. 4. With increment of the thickness of p-GaAsN the absorption of light increases which are reported in the earlier studies [8, 31-33]. For achieving maximum efficiency as well as reducing the materials cost, the optimum thickness of p-GaAsN absorber layer is fixed at $2 \mu \mathrm{m}$ and $1.5 \mu \mathrm{m}$ for these proposed solar cells Cell 1 and Cell 2, respectively.

\subsection{Influence of doping concentration on PV parameters}

In order to investigate the impact of doping density, the acceptor density $N_{A}$ in $\mathrm{p}^{+}-\mathrm{GaAs}$ and $\mathrm{p}^{++}-$ GaAs layers is varied from $5.0 \times 10^{14}$ to $1.0 \times 10^{20} \mathrm{~cm}^{-3}$ for Cell 1 and Cell 2, respectively as depicted in Figs. 5 (a) and 5(b). With increasing $N_{A}$, the values of $J_{s c}$ initially increases for Cell 1 and remains almost constant from $N_{A}=1.0 \times 10^{16} \mathrm{~cm}^{-3}$ up to $N_{A}=1.0 \times 10^{20} \mathrm{~cm}^{-3}$ (Fig. 5(a)), while no change of the value of $J_{s c}$ observed for the Cell 2 (Fig. 5(b)). In contrast, the value of $V_{o c}$ rises from $832 \mathrm{mV}$ to $1054 \mathrm{mV}$ and $1058 \mathrm{mV}$ to $1105 \mathrm{mV}$ for Cell 1 and Cell 2, respectively which results in the enhancement of the $\eta$. The reason for the increase of the $J_{s c}$ and $V_{o c}$ in Cell 1 is due to the enhancement of the reverse saturation current and electrical conductivity [15, 34]. At the value of large $N_{A}$, recombination of electron-hole pair reduces the number of carrier at the electrode which results in constant $J_{s c}[30,34]$. As shown in Fig. 5 (c), there is no effect of $V_{o c}$, 
$J_{s c}, F F$, and $\eta$ on acceptor density in the $\mathrm{p}^{+}$-AlGaAs layer. The value of $V_{o c}$ and $\eta$ increases abruptly as the donor density $N_{D}$ reaches at $10^{19} \mathrm{~cm}^{-3}$ in n-AlGaAs as illustrated in Fig. 5(d). The similar tendency was observed in the previous studies of [16, 35]. The Figs. 5 (e) and 5(f) represent the effect of $N_{A}$ inside GaAsN on the output parameters for both Cell 1 and Cell 2. For Cell 1, initially the value of $V_{o c}$ and $F F$ decreases from 1054 to $1046 \mathrm{mV}$ and 88.03 to 84.89 for the range of $N_{A}$ from $10^{14}$ to $10^{17}$ and $10^{14}$ to $10^{16} \mathrm{~cm}^{-3}$, respectively. After that it increases up to the value of $N_{A}=10^{20} \mathrm{~cm}^{-3}$ (Fig 5 (e)). While the value of $J_{s c}$ first increases and remains constant up to $N_{A}=10^{19} \mathrm{~cm}^{-3}$, then it decreases at higher density of $N_{A}$. The overall $\eta$ of the solar Cell 1 , initially deceases to minimum value of $40.05 \%$ at $N_{A}=10^{16} \mathrm{~cm}^{-3}$, then it rises to $42.36 \%$ at $N_{A}=10^{19} \mathrm{~cm}^{-3}$ (Fig 5 (f)). On the contrary, the $V_{o c}, F F, J_{s c}$ and $\eta$ remain constant up to the value of $N_{A}=10^{19} \mathrm{~cm}^{-3}$ for Cell 2. Then, all the output parameters reduce with increasing $N_{A}$ density.

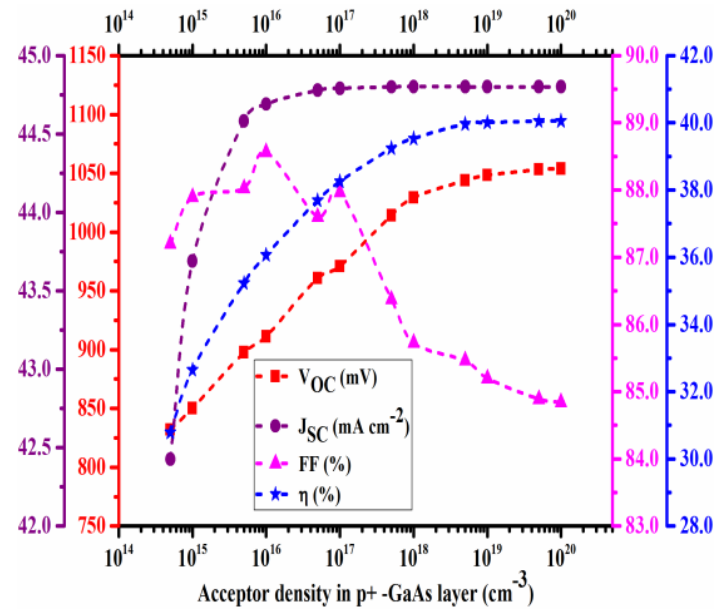

(a)

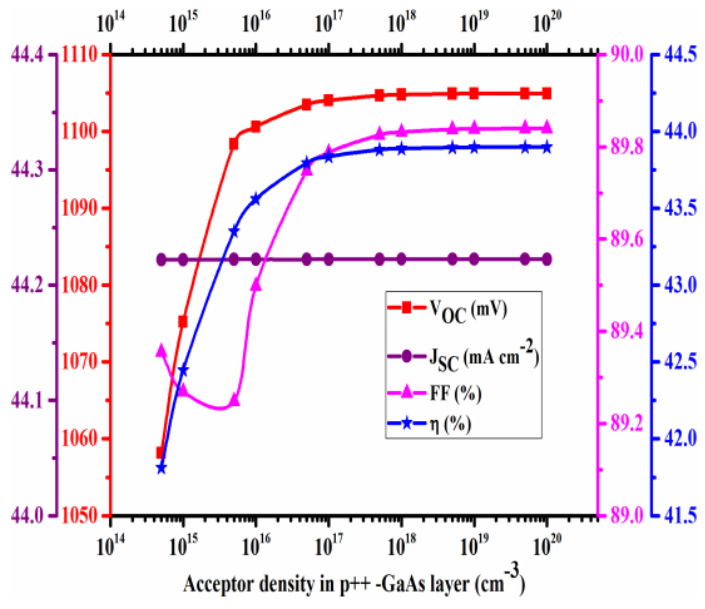

(b) 


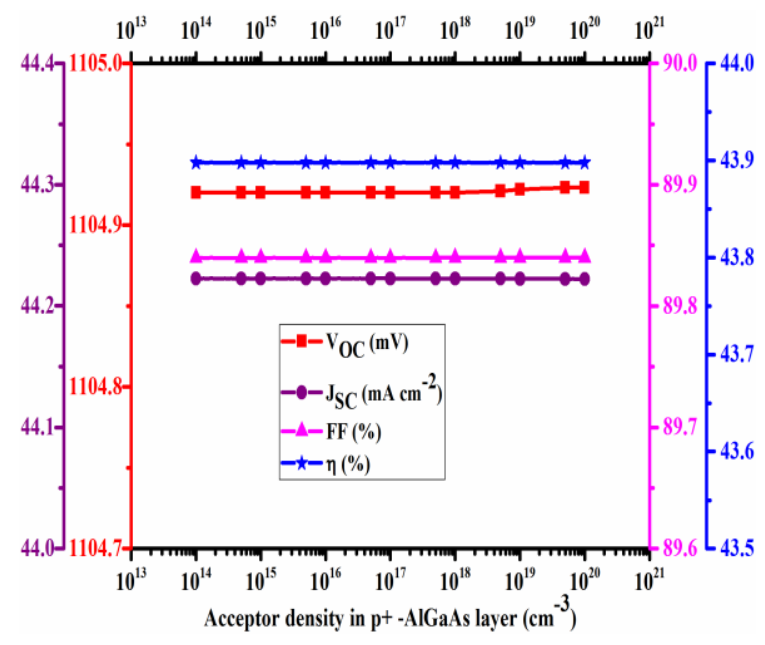

(c)

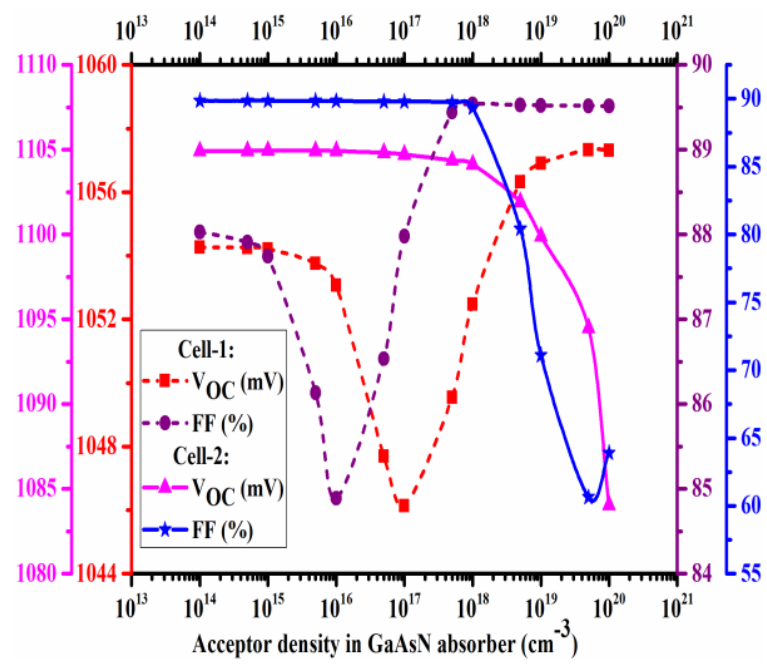

(e)

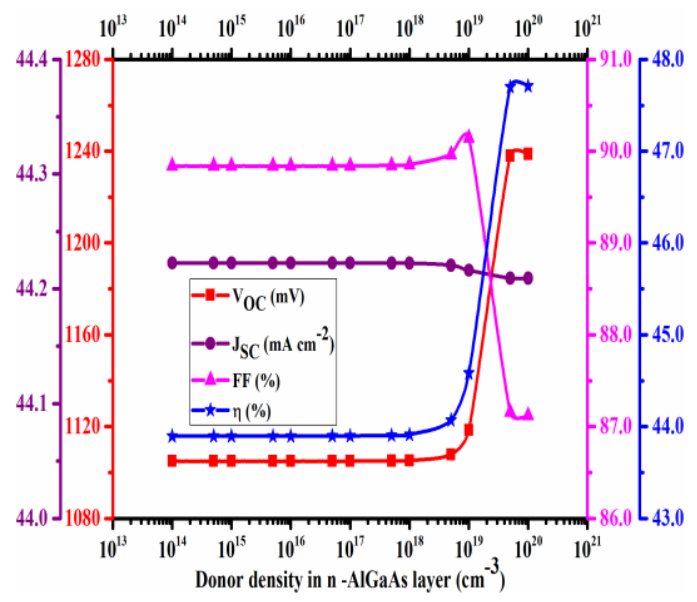

(d)

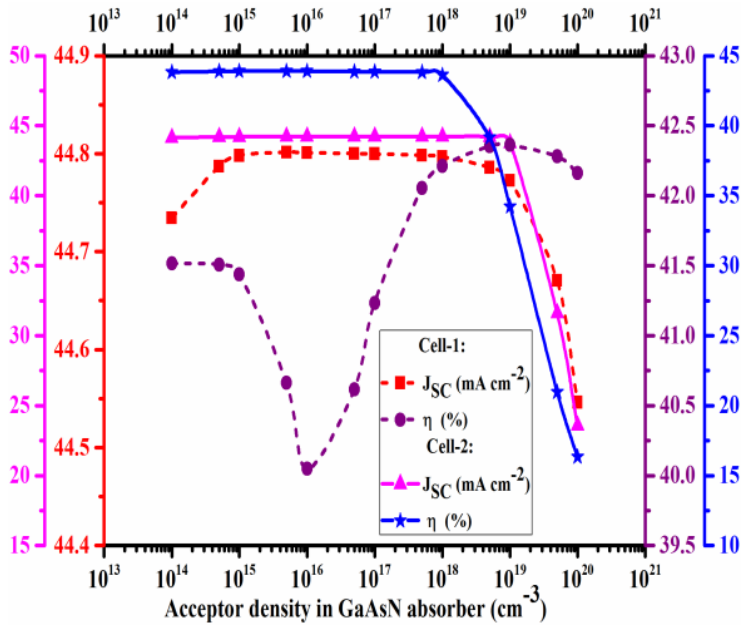

(f) 


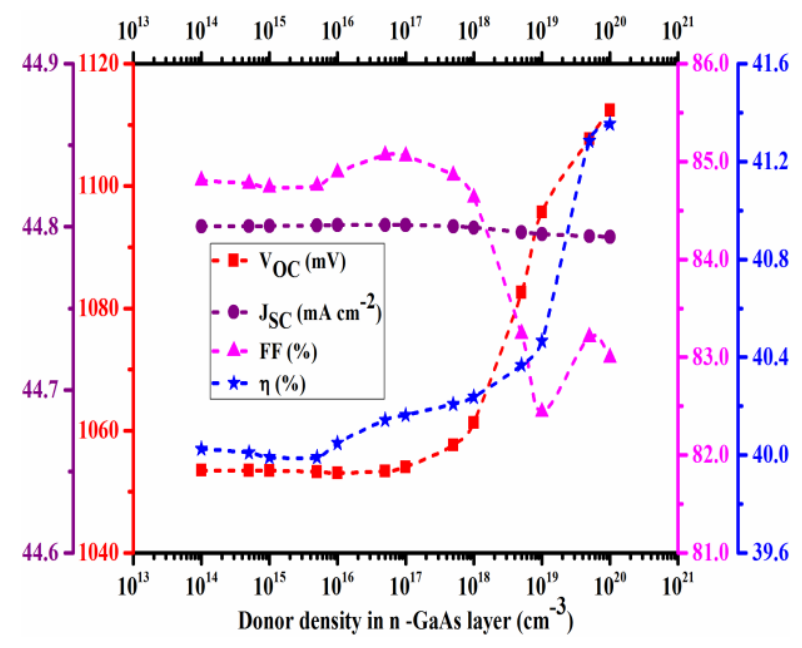

(g)

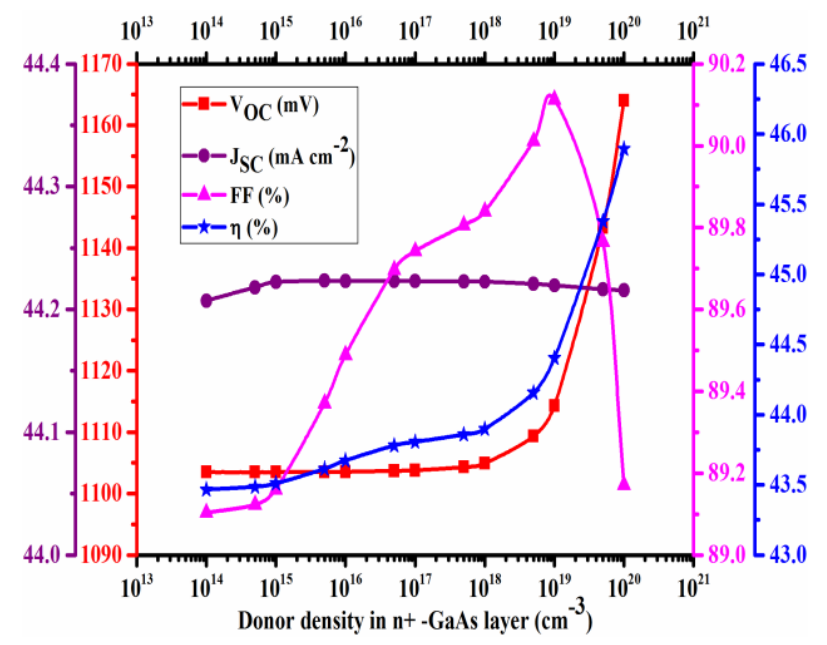

(h)

Fig. 5: The influence of doping density on the photovoltaic performance parameters (a) $p^{+}-G a A s$ layer of Cell 1 (b) $\mathrm{p}^{++}$-GaAs layer in Cell 2 (c) $\mathrm{p}^{+}$-AlGaAs layer of Cell 2 (d) n-AlGaAs layers of Cell 2 (e) and (f) p-GaAsN layer in Cell 1and Cell 2 (g) n-GaAs layer in Cell 1 and (h) $n^{+}-G a A s$ layer in Cell 2. Here the 'broken line' indicate the data for Cell 1 whereas, the solid lines for Cell 2.

With the enhancement of $N_{A}$ density, reverse saturation current reduces which results in small rise of $V_{o c}$. Finally, the value of $\eta$ increases. After the density of $N_{A}=10^{19} \mathrm{~cm}^{-3}$, all the solar cell performance parameters $\left(V_{o c}, J_{s c}, F F\right.$ and $\left.\eta\right)$ tend to degrade due to the reduction of minority carrier lifetime as well as number of photo-generated carriers inside p-GaAsN absorber layer for both solar cells. From $N_{A}$ density $10^{17}$ to $10^{20} \mathrm{~cm}^{-3}$, the $V_{o c}$ increase only $11 \mathrm{mV}$. A similar phenomenon has been discussed in earlier studies of $[28,34]$. The figures $5(\mathrm{~g})$ and $5(\mathrm{~h})$ represent the effect of donor doping density $N_{D}$ on output parameters. With increasing the donor density $N_{D}$ in $\mathrm{n}-\mathrm{GaAs}$ and $\mathrm{n}^{+}-\mathrm{GaAs}$ layers for both Cell1 and Cell 2, respectively $V_{o c}$ and $\eta$ increases, while $J_{s c}$ remains constant. The primary reason behind this enhancement of the $\eta$ is the improvement of the electrical conductivity and $V_{o c}$ in $\mathrm{n}-\mathrm{GaAs}$ and $\mathrm{n}^{+}-\mathrm{GaAs}$ layer due to the addition of large number of free electrons [28, 34]. 


\subsection{Impact of defect density on PV parameters}

The impact of total density of defect on the photovoltaic output parameters for the different layers of both the solar cells (Cell 1 and Cell 2) are depicted in Fig. 6.

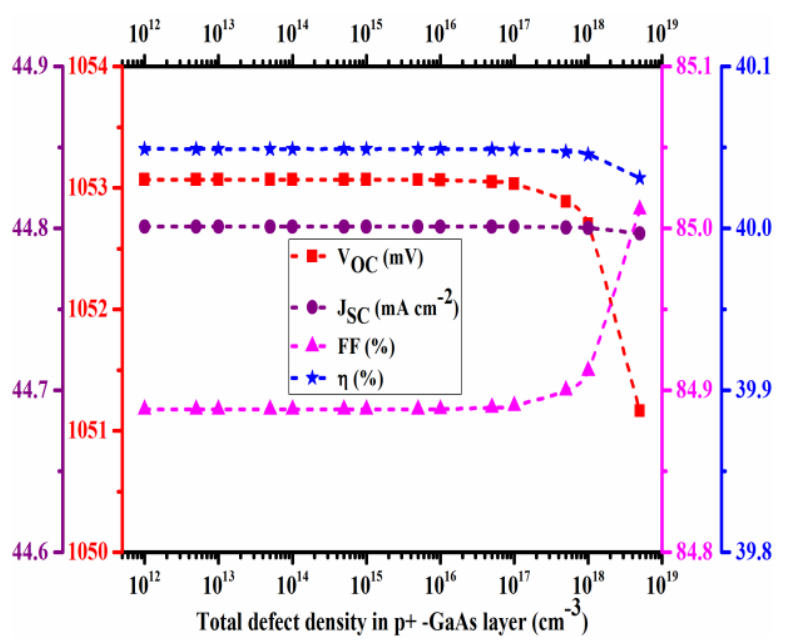

(a)

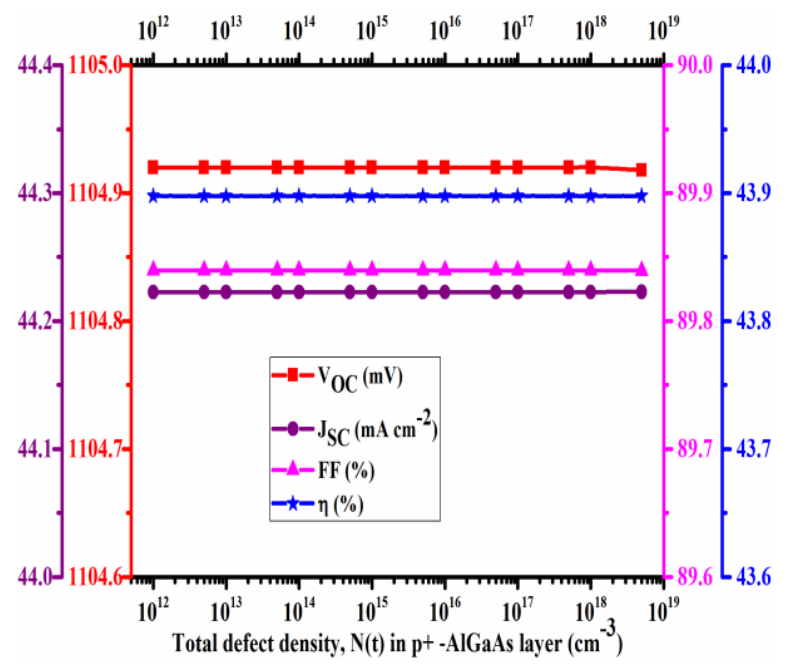

(c)

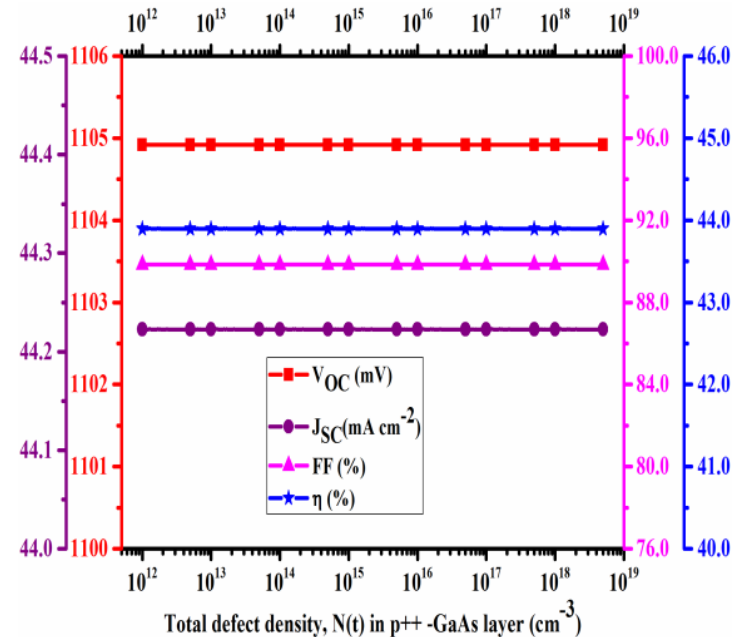

(b)

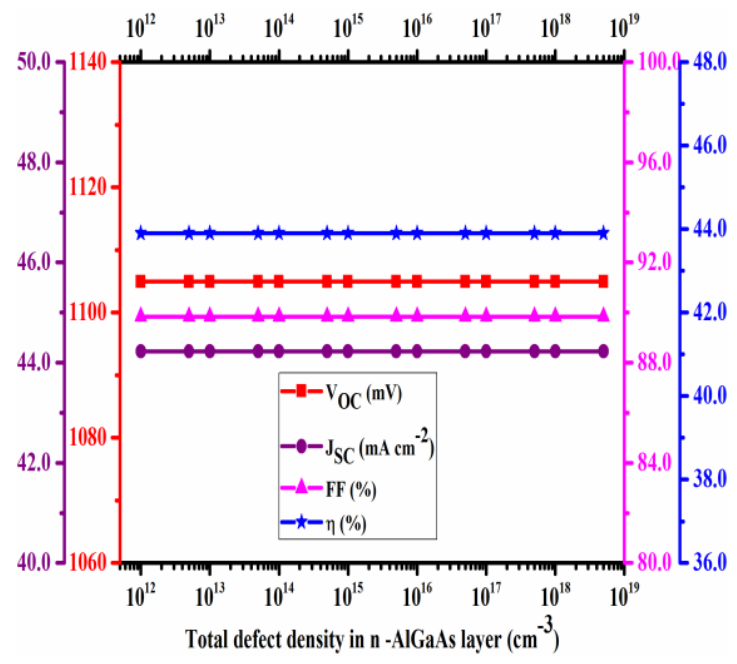

(d) 


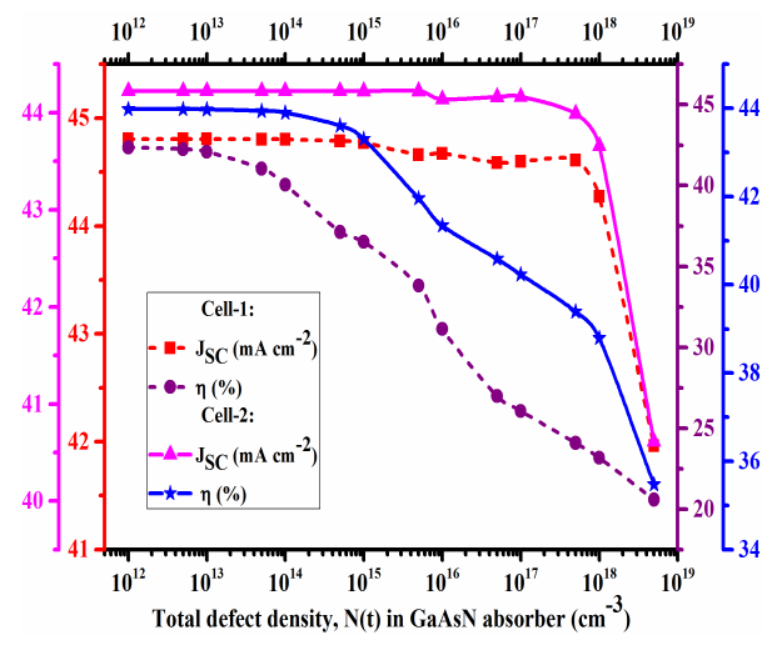

(e)

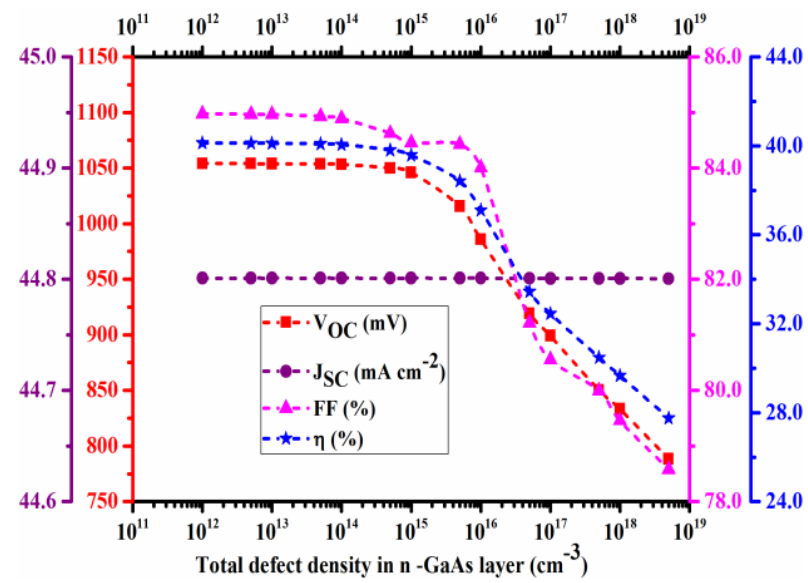

(g)

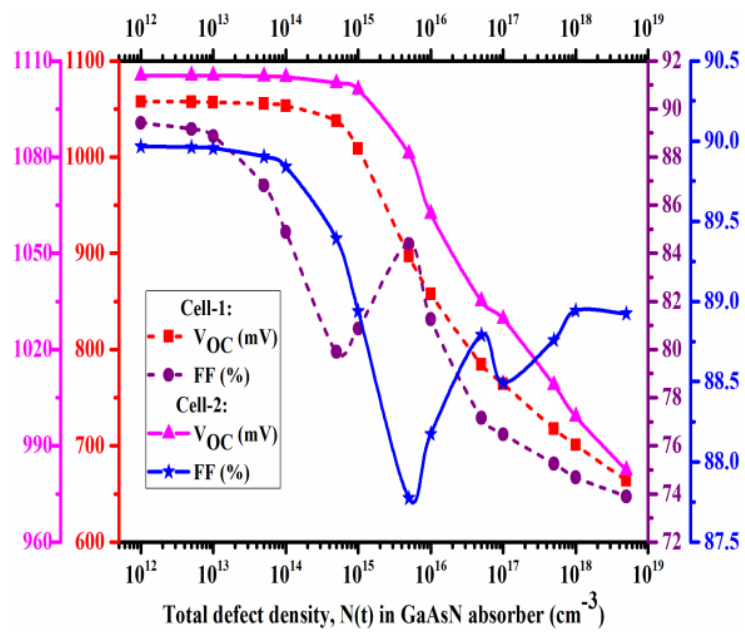

(f)

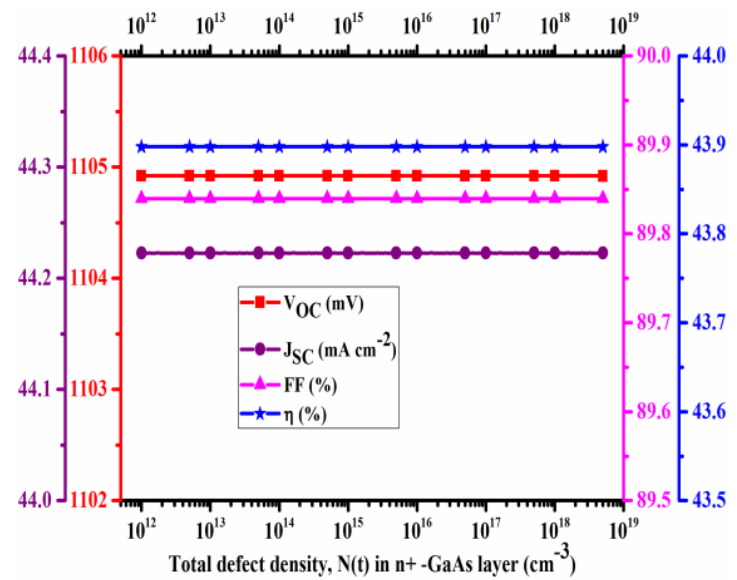

(h)

Fig. 6 The impact of total defect density on the photovoltaic performance parameters.(a) $\mathrm{p}^{+}$-GaAs layer of Cell 1, (b) $\mathrm{p}^{++}$-GaAs layer in Cell 2, (c)and (d) $\mathrm{p}^{+}$-AlGaAs and n- AlGaAs layers in Cell 2, (e) and (f) p-GaAsN layer in Cell 1and Cell 2, (g) n-GaAs layer in Cell 1 and (h) $\mathrm{n}^{+}-\mathrm{GaAs}$ layer in Cell 2. Here the 'broken lines' indicate the data for Cell 1 whereas, the solid lines for Cell 2.

As shown in Fig. 6(a), the values of $V_{o c}, J_{s c}$ and $\eta$ start to decrease at the total defect density of $5.0 \times 10^{18} \mathrm{~cm}^{-3}$ while the value of FF shows increasing tendency from $5.0 \times 10^{17} \mathrm{~cm}^{-3}$ for the $\mathrm{p}^{+}-$ GaAs layer in Cell 1. On the contrary, all the solar cell performance parameters $\left(V_{o c}, J_{s c}, F F\right.$ and 7) of $\mathrm{p}^{++}-\mathrm{GaAs}, \mathrm{p}-\mathrm{AlGaAs}$ and $\mathrm{n}-\mathrm{AlGaAs}$ layers in Cell 2 remain constant with changing the total defect density as indicated in Figs. 6(b), 6(c) and 6(d), respectively. A similar results was found in the previous report $[12,36]$. The value of the total defect density of p-GaAsN layer is varied from $1.0 \times 10^{12}$ to $5.0 \times 10^{18} \mathrm{~cm}^{-3}$ and the significant impact of the total defect density on the 
PV parameters has been represented in Figs. 6 (e) and 6(f). The Cell1 and Cell 2 can endure the total defect density about $10^{14} \mathrm{~cm}^{-3}$ to obtain $\eta$ of $40.05 \%$ and $43.90 \%$, respectively. At the maximum defect density of $5.0 \times 10^{18} \mathrm{~cm}^{-3}$, both Cell 1 and Cell 2 demonstrate least efficiency of $20.58 \%$ and $35.48 \%$ respectively. All the PV performance parameters degrade significantly at higher defect densities. The Shockley-Read-Hall (SRH) recombination rate contributes to decrease the PV performance parameters of the $\mathrm{p}-\mathrm{GaAsN}$ absorber layer due to the existence of high defect density. The SRH recombination decreases the number of photo-generated carriers as well as the $V_{o c}$, thus reduces the $F F$ and $\eta$. The solar cell devices are significantly affected due to the existence of interface and bulk defects that decreases the minority carrier life time and diffusion length $[12,36]$.

With increasing defect density of the layer $\mathrm{n}-\mathrm{GaAs}$ in Cell 1 , the value of solar cell performance parameters $\left(V_{o c}, J_{s c}, F F\right.$ and $\left.\eta\right)$ decreases due to the reduction of the free carriers as well as electrical conductivity, however no variation is observed of the output parameters of $n^{+}-G a A s$ layer in Cell 2 as depicted in Figs. 6 (g) and 6(h). A similar tendency was found in the previous report of [37].

\subsection{Effect of temperature on performance parameters:}

Considering the thickness of $2000 \mathrm{~nm}$ of p-GaAsN absorber layer, the temperature is varied from 273K to 373K of solar Cell 1 and Cell 2 as represented in Figs. 7(a) and 7(b). The temperature dominantly contributes to decrease the value of $V_{o c}$ in Cell 1 and Cell 2 which results in decrease of the overall efficiency. The rise of temperature in Cell 1 and Cell 2 increases the reverse saturation current which also reduces $V_{o c}$ almost linearly from 1099 to $950 \mathrm{mV}$ and 1140 to1006 $\mathrm{mV}$, respectively. The values of $\eta$ also decreases from 41.97 to $34.37 \%$ and 45.75 to $38.62 \%$ and for Cell 1 and Cell 2, respectively. 


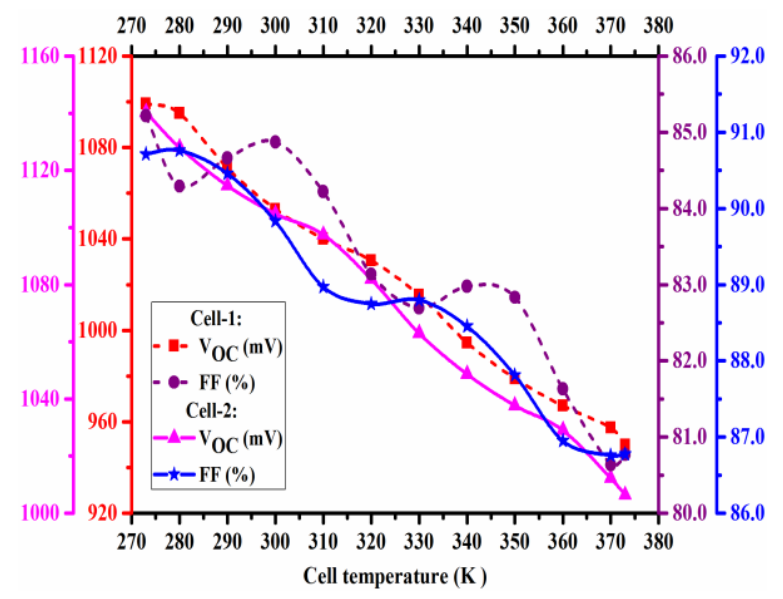

(a)

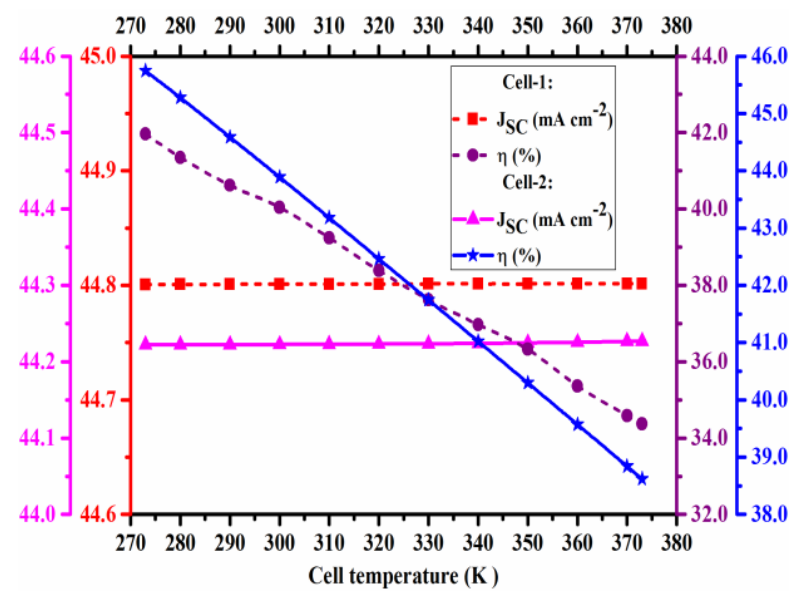

(b)

Fig. 7 Effect of temperature on solar cell performance parameters: (a) $V_{o c}$ and $F F$, and (b) $J_{s c}$ and $\eta$ for Cell 1 and Cell 2. Here the 'broken lines' indicate the data for Cell 1 whereas, the solid lines for Cell 2.

The semiconductor materials bandgap, $E_{g}$ decreases with rising in temperature due to reduction of the bonding energy and the electron-hole recombination processes enhances. Thus, the number electron-hole also reduces due to temperature rise which maintains constant $J_{s c}$ for Cell1 and Cell 2 over the range of temperature that are generated due to reduction of $E_{g}[37,38]$. The $F F$ decreases for the combined effect of the $V_{o c}, J_{s c}$, and $\eta$.

\subsection{Enhancement of performance parameter $p-G a A s N$ solar cell}

The electrical characteristics (J-V) curve of the designed p-GaAsN dilute nitride solar cells with and without AlGaAs blocking layer has been demonstrated in Fig. 8 at $300 \mathrm{k}$ under illumination of $100 \mathrm{mWcm}^{-2}$. The solar cell with AlGaAs blocking layer (Cell 2), demonstrates the improved performance parameters $V_{o c}=1105 m V, J_{s c}=44.22 \mathrm{mAcm}^{-2}, F F=89.84$, and $\eta=43.90$, which is larger than the solar cell without AlGaAs blocking layer (Cell 1) in which $V_{o c}=1053 \mathrm{mV}, J_{s c}=$ $44.80 \mathrm{mAcm}^{-2}, F F=84.89$, and $\eta=40.05$. The present study proclaims a new insight to obtain the outmost efficiency of $43.90 \%$ and $40.05 \%$ for Cell 2 and Cell 1, respectively. The optimal PV performance parameters in the present study at $300 \mathrm{~K}$ and the comparison of performance of our achieved results with the previously studied values are demonstrated in Table 2 and Table 3 , respectively. 


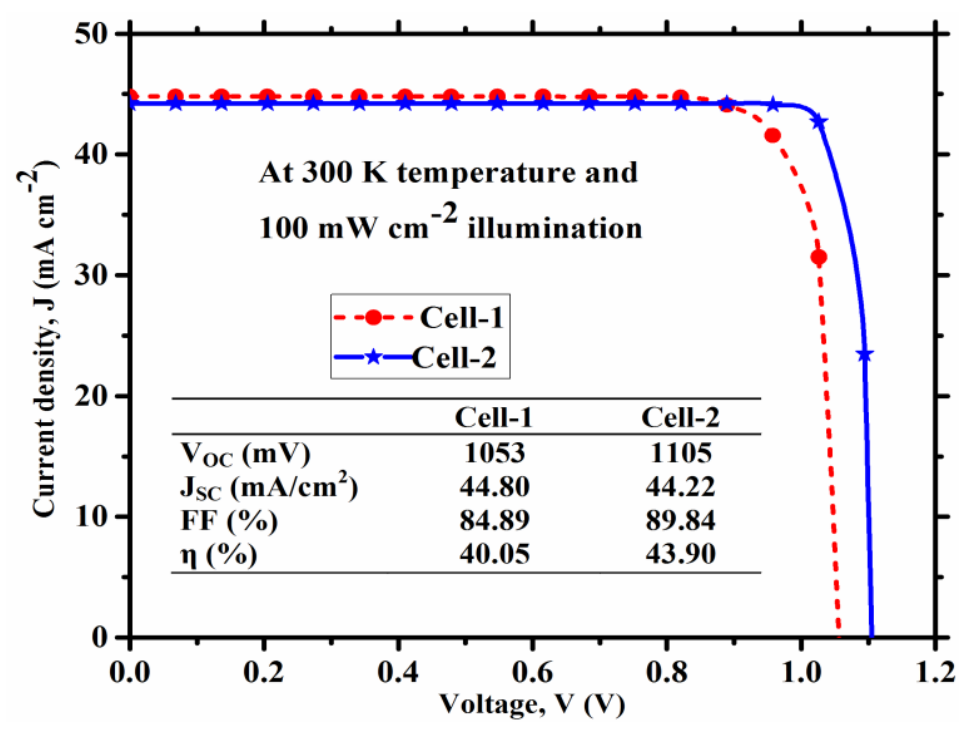

Fig. 8 the electrical J-V characteristics of the designed solar cells.

Table 2: Comparison of the performance parameters in present study at $300 \mathrm{~K}$.

\begin{tabular}{|c|c|c|c|c|c|c|c|c|}
\hline No. & $\begin{array}{c}\text { Studied } \\
\text { solar cell }\end{array}$ & $\begin{array}{c}\text { GaAsN } \\
\text { depth } \\
(\mathrm{nm})\end{array}$ & $\begin{array}{c}J_{s c} \\
\left(\mathrm{mAcm}^{-2}\right)\end{array}$ & $\begin{array}{c}J_{m p} \\
\left(\mathrm{mAcm}^{-2}\right)\end{array}$ & $\begin{array}{c}V_{o c} \\
(\mathrm{mV})\end{array}$ & $\begin{array}{c}V_{m p} \\
(\mathrm{mV})\end{array}$ & $\begin{array}{c}F F \\
(\%)\end{array}$ & $\begin{array}{c}\text { PCE } \\
(\%)\end{array}$ \\
\hline 1 & Cell 1 & 2000 & 44.80 & 42.71 & 1053 & 936 & 84.89 & 40.05 \\
\hline 2 & Cell 2 & 2000 & 44.22 & 43.11 & 1105 & 1019 & 89.84 & 43.90 \\
\hline
\end{tabular}

Table 3: summary of the PV parameter of our present study with the previously studied values. $($ Expt. $=$ Experimental, Theo. $=$ Theoretical $)$

\begin{tabular}{|c|c|c|c|c|c|c|c|c|}
\hline No. & $\begin{array}{c}\text { Research } \\
\text { Type }\end{array}$ & Structure & $\begin{array}{c}\text { GaAsN } \\
\text { depth }(\mathrm{nm})\end{array}$ & $\begin{array}{c}J_{s c} \\
\left(\mathrm{mAcm}^{-2}\right)\end{array}$ & $\begin{array}{c}V_{o c} \\
(\mathrm{mV})\end{array}$ & $\begin{array}{c}\text { FF } \\
(\%)\end{array}$ & $\begin{array}{c}\text { PCE } \\
(\%)\end{array}$ & Ref. \\
\hline 1 & Theo. & $\begin{array}{c}\mathrm{p}-\mathrm{GaAs} / \mathrm{p}-\mathrm{GaAsN} / \mathrm{n}- \\
\text { GaAs }\end{array}$ & 2000 & 30.31 & 930 & - & 24.94 & {$[14]$} \\
\hline 2 & Theo. & $\mathrm{p}-\mathrm{GaAsN} / \mathrm{n}-\mathrm{GaAsN}$ & 1500 & 68 & 790 & 68 & 38.20 & {$[22]$} \\
\hline
\end{tabular}




\begin{tabular}{|c|c|c|c|c|c|c|c|c|}
\hline 3 & Theo. & $\begin{array}{c}\mathrm{n}+-\mathrm{GaAs} / \mathrm{n}+- \\
\mathrm{GaAsN} / \mathrm{p}-\mathrm{GaAsN}\end{array}$ & - & 25.00 & 800 & 76 & 15.00 & {$[15]$} \\
\hline 4 & Theo. & $\begin{array}{l}\text { n-AlInP/n-GaAs/n- } \\
\text { AlGaAs/p-AlGaAs }\end{array}$ & 500 & 30 & 1108 & 86.50 & 28.70 & [19] \\
\hline 5 & Theo. & $\mathrm{AlGaAs} / \mathrm{GaAs}$ & - & 36.9 & 970 & 80.82 & 28.72 & [28] \\
\hline 6 & Expt. & $\begin{array}{l}\text { n-InGaP/nGaAsSbN/ } \\
\text { p-GaAsSbN/p-InGaP }\end{array}$ & 600 & 11.59 & 830 & 72.58 & 7.00 & {$[33]$} \\
\hline 7 & Theo. & $\begin{array}{c}\text { GaInP/GaAs/GaInNA } \\
\mathrm{s}\end{array}$ & 500 & 17.10 & 2815 & - & 30.10 & [13] \\
\hline 8 & Theo. & GaInNAs & 700 & 24.50 & 460 & - & 29.00 & [13] \\
\hline 9 & Theo. & $\begin{array}{l}\text { n-GaAs/p-GaAsN/n- } \\
\text { GaAs }\end{array}$ & 2000 & 44.80 & 1053 & 84.89 & 40.05 & $\begin{array}{l}\text { This } \\
\text { work }\end{array}$ \\
\hline 10 & Theo. & $\begin{array}{c}\text { n-GaAs/n-AlGaAs/p- } \\
\text { GaAsN/p-AlGaAs/p- } \\
\text { GaAs }\end{array}$ & 2000 & 44.22 & 1105 & 89.84 & 43.90 & $\begin{array}{l}\text { This } \\
\text { work }\end{array}$ \\
\hline
\end{tabular}

The Table 3 illustrates the comparison of the development of GaAsN solar cell structures by different research groups. The theoretical approaches in the previous study show that the efficiency enhances from $15.0 \%$ to the highest $38.20 \%$ till now. From the simulation works, we have determined larger $V_{o c}$ and $\eta$ compared to the reported values [13, 14, 22, 28]. The value of $F F$ and $J_{s c}$ obtained from the numerical study is also higher than that in most of the previous reported values. The present study provides the insight for the guideline to obtain outmost efficiency of $40.05 \%$ and $43.90 \%$ for GaASN solar cell without and with AlGaAs blocking layer.

\section{Conclusions}

Dilute nitride solar cells of $\mathrm{p}$-GaAsN absorber layer, have been designed to exploit absorption of light in the wide range and investigated in detail. The numerical study has been done by SCAPS$1 D$ simulator to analyze the impact of layer thickness, defect and doping density, and temperature variation on the output parameters such as $J_{s c}, V_{o c}, F F$ and $\eta$. The numerical simulated output indicates that the solar cell containing AlGaAs blocking layers (Cell 2) exhibits an overall efficiency of $43.90 \%$ with doping density of $1.0 \times 10^{16} \mathrm{~cm}^{-3}$ and defect density of $1.0 \times 10^{14} \mathrm{~cm}^{-3}$ in the $2000 \mathrm{~nm}$ thick $\mathrm{p}-\mathrm{GaAsN}$ absorber layer. On the other hand, the solar cell (Cell 1)containing no blocking layers shows the efficiency of $40.05 \%$ at the same doping and defect densities of the same absorber layer and its thickness. The present study leads toward the 
realization of high-efficiency dilute nitride solar cell for the applications in space and PV industries.

\section{Acknowledgements}

The authors would like to thank Marc Burgelman, Department of Electronics and Information System, University of Gent, Belgium for allowing the opportunity to use SCAPS-1D for simulation.

\section{Declaration of Competing Interest}

The authors declare that they have no competing interest related to the financial or personal relationship.

\section{References}

1. Tang, D., Vijaya, G.K., Mehrotra, A., Freundlich, A., Smith, D.J.: Investigation of dilutenitride alloys of GaAsNx $(0.01<\mathrm{x}<0.04)$ grown by MBE on GaAs (001) substrates for photovoltaic solar cell devices. J. Vac. Sci. Technol. B, Nanotechnol. Microelectron. Mater. Process. Meas. Phenom. 34, 011210 (2016). https://doi.org/10.1116/1.4940127

2. Yamaguchi, M., Bouzazi, B., Suzuki, H., Ikeda, K., Kojima, N., Ohshita, Y.: III-V-N materials for super high-efficiency multijunction solar cells. AIP Conf. Proc. 1477, 24-27 (2012). https://doi.org/10.1063/1.4753825

3. Li, J., Aierken, A., Liu, Y., Zhuang, Y., Yang, X., Mo, J.H., Fan, R.K., Chen, Q.Y., Zhang, S.Y., Huang, Y.M., Zhang, Q.: A Brief Review of High Efficiency III-V Solar Cells for Space Application. Front. Phys. 8, 1-15 (2021). https://doi.org/10.3389/fphy.2020.631925

4. Buyanova, I.A., Chen, W.M., Pozina, G., Bergman, J.P., Monemar, B., Xin, H.P., Tu, C.W.: Mechanism for low-temperature photoluminescence in GaNAs/GaAs structures 
grown by molecular-beam epitaxy. Appl. Phys. Lett. 75, 501-503 (1999).

https://doi.org/10.1063/1.124429

5. Osada, K., Suzuki, T., Yagi, S., Naitoh, S., Shoji, Y.: Control of intermediate-band con fi guration in GaAs : N $\delta$-doped superlattice. 04, 9-11 (2015)

6. $\quad$ Haque, M.D., Kamata, N., Islam, A.Z.M.T., Honda, Z., Yagi, S., Yaguchi, H.:

Photoluminescence characterization of nonradiative recombination centers in MOVPE grown GaAs:N $\delta$-doped superlattice structure. Opt. Mater. (Amst). 89, 521-527 (2019). https://doi.org/10.1016/j.optmat.2019.01.047

7. Krispin, P., Gambin, V., Harris, J.S., Ploog, K.H.: Nitrogen-related electron traps in Ga(As,N) layers ( $\leq 3 \%$ N). J. Appl. Phys. 93, 6095-6099 (2003).

https://doi.org/10.1063/1.1568523

8. Ikeda, K., Hwang, J.H., Inagaki, M., Kojima, N., Ohshita, Y., Yamaguchi, M.: Fabrication of GaAsN solar cell by chemical beam epitaxy with improved minority-carrier lifetime. Conf. Rec. IEEE Photovolt. Spec. Conf. 2540-2542 (2012).

https://doi.org/10.1109/PVSC.2012.6318112

9. Shafi, M., Mari, R.H., Henini, M., Taylor, D., Hopkinson, M.: Electrical properties of nitrogen-related defects in n-type GaAsN grown by molecular-beam epitaxy. Phys. Status Solidi Curr. Top. Solid State Phys. 6, 2652-2654 (2009).

https://doi.org/10.1002/pssc.200982561

10. Ullah, Hanif; Mari, Bernabe; Sanchez Ruiz, L.: Effect of defects on the performance of some photovoltaic solar cells : an introduction to research methods to engineering students. 44 SEFI Conf. 12-15 (2016)

11. Haque, M.D., Kamata, N., Islam, A.Z.M.T., Yagi, S., Yaguchi, H.: Spectral Change of E - Band Emission in a GaAs:N $\delta$-Doped Superlattice Due to Below-Gap Excitation and Its Discrimination from Thermal Activation. J. Electron. Mater. 49, 1550-1556 (2020). https://doi.org/10.1007/s11664-019-07856-6

12. Han, X., Hwang, J.H., Kojima, N., Ohshita, Y., Yamaguchi, M.: Effects of a key deep level and interface states on the performance of GaAsN solar cells: A simulation analysis. Semicond. Sci. Technol. 27, (2012). https://doi.org/10.1088/0268-1242/27/10/105013 
13. Aho, A., Isoaho, R., Tukiainen, A., Gori, G., Campesato, R., Guina, M.: Dilute nitride triple junction solar cells for space applications: Progress towards highest AM0 efficiency. Prog. Photovoltaics Res. Appl. 26, 740-744 (2018). https://doi.org/10.1002/pip.3011

14. Boumesjed, A., Mazari, H., Ameur, K.: Predicted Theoretical Efficiency for New Intermediate Band Solar Cells (IBSC) Based on GaAs1-xNx. J. New Technol. Mater. 8, 102-109 (2018). https://doi.org/10.12816/0048938

15. Wang, L., Elleuch, O., Kojima, N., Ohshita, Y., Yamaguchi, M.: Simulation Analysis of The Potential Causes for The Low Jsc in GaAsN Solar Cells. 390-391 (2017). https://doi.org/10.7567/ssdm.2014.ps-15-1

16. Narasimhan, V.K., Yastrebova, N., Valdivia, C.E., Hall, T.J., Hinzer, K., Masson, D., Fafard, S., Jaouad, A., Arès, R., Aimez, V.: Effect of parameter variations on the currentvoltage behavior of AlGaAs tunnel junction models. 1st Microsystems Nanoelectron. Res. Conf. MNRC 2008 - Enabling Synerg. Accel. Excell. Grad. Student Res. 165-168 (2008). https://doi.org/10.1109/MNRC.2008.4683404

17. Burgelman, M., Decock, K., Kheli, S., Abass, A.: Author's personal copy Advanced electrical simulation of thin fi lm solar cells. Thin Solid Films. 535, 296-301 (2013)

18. M. Levinstein, S.R. a M.S.: Handbook Series on Semiconductor Parameters. In: WorldScientific, London (1996)

19. Hwang, S.T., Kim, S., Cheun, H., Lee, H., Lee, B., Hwang, T., Lee, S., Yoon, W., Lee, H.M., Park, B.: Bandgap grading and A10.3Ga0.7As heterojunction emitter for highly efficient GaAs-based solar cells. Sol. Energy Mater. Sol. Cells. 155, 264-272 (2016). https://doi.org/10.1016/j.solmat.2016.06.009

20. Chan, H.C., Shieh, T.J.: A Three-Dimensional Semiconductor Device Simulator for GaAs/Algaas Heterojunction Bipolar Transistor Analysis. IEEE Trans. Electron Devices. 38, 2427-2432 (1991). https://doi.org/10.1109/16.97405

21. No Title, www.ioffe.ru/SVA/NSM/Semicond/GaAs/index.html

22. Ameur, K., Mazari, H., Benseddik, N.: Optimization of a GaAsN Ternary Alloy Based Solar Cell for High Efficiency. J. New Technol. Mater. 8, 114-119 (2018). https://doi.org/10.12816/0048930 
23. S. W. Koch, M.: Theory of Semiconductors: Quantum Kinetics. In: Confinement and Lasers. p. 212. World Scientific (1995)

24. No Title, www.ioffe.ru/SVA/NSM/Semicond/AlGaAs/index.html

25. B. Boittiaux, C. électronique: Les composants semiconducteurs. Presented at the (1995)

26. Debbar, N., Al-Mashary, B.: Numerical simulation of GaAs/AlGaAs heterojunctions including interface states and thermionic emission. Int. J. Model. Simul. 23, 103-108 (2003). https://doi.org/10.1080/02286203.2003.11442260

27. Andre, C.L., Wilt, D.M., Pitera, A.J., Lee, M.L., Fitzgerald, E.A., Ringel, S.A.: Impact of dislocation densities on $\mathrm{n}+/ \mathrm{p}$ and $\mathrm{p}+/ \mathrm{n}$ junction GaAs diodes and solar cells on SiGe virtual substrates. J. Appl. Phys. 98, (2005). https://doi.org/10.1063/1.1946194

28. Laznek, S., Meftah, A., Meftah, A., Sengouga, N.: Semi-Analytical Simulation and Optimization of AlGaAs/GaAs p-i-n Quantum Well Solar Cell. Appl. Sol. Energy (English Transl. Geliotekhnika). 54, 261-269 (2018). https://doi.org/10.3103/S0003701X18040126

29. Sumaryada, T., Fitriansyah, P., Sofyan, A., Syafutra, H.: Modeling the output performance

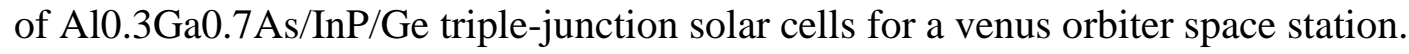
Photonics. 6, (2019). https://doi.org/10.3390/photonics6020046

30. Yanwachirakul, W., Miyashita, N., Sodabanlu, H., Watanabe, K., Sugiyama, M., Okada, Y., Nakano, Y.: Carrier Collection Improvement in InGaAs/GaAsN Multiple Quantum Well Solar Cell with Flat Conduction Band. 2018 IEEE 7th World Conf. Photovolt. Energy Conversion, WCPEC 2018 - A Jt. Conf. 45th IEEE PVSC, 28th PVSEC 34th EU PVSEC. 1874-1877 (2018). https://doi.org/10.1109/PVSC.2018.8548083

31. Welser, R.E., Sood, A.K., Laghumavarapu, R.B., Huffaker, D.L., Wilt, D.M., Dhar, N.K., Sablon, K.A.: The Physics of High-Efficiency Thin-Film III-V Solar Cells. (2015)

32. Kato, Y., Fujimoto, S., Kozawa, M., Fujiwara, H.: Maximum efficiencies and performance-limiting factors of inorganic and hybrid perovskite solar cells. Phys. Rev. Appl. 12, 1-41 (2019). https://doi.org/10.1103/PhysRevApplied.12.024039

33. Kim, T.W., Kim, Y., Kim, K., Lee, J.J., Kuech, T., Mawst, L.J.: 1.25-eV GaAsSbN/Ge 
double-junction solar cell grown by metalorganic vapor phase epitaxy for high efficiency multijunction solar cell application. IEEE J. Photovoltaics. 4, 981-985 (2014). https://doi.org/10.1109/JPHOTOV.2014.2308728

34. Samoura, A., Sakho, O., Faye, O., Beye, A.C.: Base Doping Effects on the Efficiency of Vertical Parallel Junction Solar Cells. Open J. Appl. Sci. 07, 282-290 (2017). https://doi.org/10.4236/ojapps.2017.76023

35. Woodall, J.M., Hovel, H.J.: High-efficiency Ga1-xAlxAs GaAs solar cells. Appl. Phys. Lett. 21, 379-381 (1972)

36. Khelifi, S., Burgelman, M., Verschraegen, J., Belghachi, A.: Impurity photovoltaic effect in GaAs solar cell with two deep impurity levels. Sol. Energy Mater. Sol. Cells. 92, 15591565 (2008). https://doi.org/10.1016/j.solmat.2008.07.003

37. Chahid, E., Oumhanad, M.I., Feddaoui, M., Malaouib, A.: Study of the physical parameters on the GaAs solar cell efficiency. J. Ovonic Res. 13, 119-128 (2017)

38. Aeberhard, U., Gonzalo, A., Ulloa, J.M.: Photocarrier extraction in GaAsSb/GaAsN typeII QW superlattice solar cells. Appl. Phys. Lett. 112, (2018).

https://doi.org/10.1063/1.5030625 